\title{
OPTIMIZATION OF EUGENOL-LOADED MICROCAPSULES OBTAINED BY SPRAY DRYING USING A SIMPLEX-CENTROID MIXTURE DESIGN
}

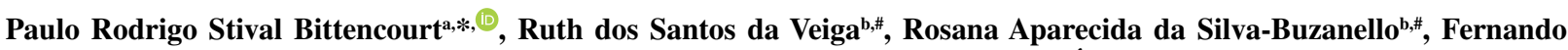 \\ Reinoldo Scremin ${ }^{\mathrm{a}}$, Tania Aparecida Becker-Algeri ${ }^{\mathrm{b}, \mathrm{c}, \#, \mathrm{~s}}$, Marinês Paula Corso ${ }^{\mathrm{b}, \#}$, Éder Lisandro de Moraes Flores $^{\mathrm{a}}$ and \\ Cristiane Canan ${ }^{\mathrm{b}, \#}$
}

aDepartamento de Química, Universidade Tecnológica Federal do Paraná, 85884-000 Medianeira - PR, Brasil

'Universidade Tecnológica Federal do Paraná, 85884-000 Medianeira - PR, Brasil

'Universidade do Rio Grande, 96203-900 Rio Grande - RS, Brasil

Recebido em 15/02/2021; aceito em 22/07/2021; publicado na web em 20/08/2021

\begin{abstract}
Eugenol antioxidant and antibacterial properties have suggested its use as a natural preservative for food matrices. Eugenol application is compromised due to its high volatility and sensibility to external agents, such as light, heat, oxygen, and moisture. Thus, microencapsulation is viable to increase the eugenol stability. Results have showed that carrageenan combined with rice protein and bovine albumin allow high-quality eugenol microcapsules. These materials show excellent properties, favoring the microcapsules use in food matrices. This study aimed to optimize microcapsules formulation by spray drying, using a simplex-centroid mixture design. Blends of low-lactose whey protein (WP) and/or rice bran protein (RBP) and/or bovine serum albumin (BSA) with carrageenan were used as wall materials. Blends influenced the eugenol retention, microencapsulation efficiency, and size. Pure WP was not efficient for eugenol encapsulation. The highest eugenol retention values, $89.7 \%$ and $86.5 \%$ were obtained by combining carrageenan with RBP or BSA. RBP and BSA binary interaction with carrageenan showed the highest encapsulation value (80.5\%). Scanning electron microscopy, infrared spectroscopy, and thermogravimetry confirmed eugenol inside the microcapsules.
\end{abstract}

Keywords: encapsulation efficiency; bovine serum albumin; low-lactose whey protein; rice bran protein.

\section{INTRODUCTION}

Eugenol $\left(\mathrm{C}_{10} \mathrm{H}_{12} \mathrm{O}_{2}\right.$; 4-allyl-2-methoxyphenol) is a phenolic compound extracted from spices and herbs, such as clove, basil, nutmeg, and cinnamon. The use of eugenol in food matrices has been suggested as a replacement for synthetic additives due to its potential antioxidant and antimicrobial characteristics. ${ }^{1-3}$ However, eugenol is a hydrophobic compound that presents high volatility and sensitivity toward external agents, such as light, heat, oxygen and moisture, hampering its large-scale use in the food industry. ${ }^{4}$ Thus, microencapsulation is a viable alternative for greater stability for eugenol application.

The spray drying method is commonly used for bioactive compounds microencapsulation, such as flavor, lipids, and carotenoids. ${ }^{5}$ The technique comprises of preparing a suspension or emulsion of materials (encapsulant and encapsulated) followed by drying, under controlled dryer temperature and in feed flow rate. Rapid solvent evaporation enables the stability of microcapsules produced, with water as one of the most used solvents in this method. ${ }^{6,7}$

Encapsulation efficiency and microcapsule stability may be influenced by the material used in microencapsulation. ${ }^{8-10}$ Despite the high variability of polymers available for use as wall material, biocompatible and biodegradable materials have been suggested for microencapsulation. Carbohydrates, gums, lipids, and proteins are a few examples of wall materials most commonly used in microencapsulation. ${ }^{11,12}$

Carrageenan is a sulfated anionic polysaccharide extracted from red seaweed (class Rhodophyceae). ${ }^{13}$ The $\kappa$-carrageenan is characterized by a linear chain of $\beta(1 \rightarrow 3)$-D-galactose sulfate and

*e-mail: paulob@utfpr.edu.br

\#Programa de Pós-Graduação em Tecnologia de Alimentos (PPGTA)

\&Programa de Pós-graduação em Engenharia e Ciência de Alimentos $\alpha(1 \rightarrow 4)-3,6$-anhydro-D-galactose units chain that may be solubilized in water under heating (above $60{ }^{\circ} \mathrm{C}$ ). After cooling, the galactose chains form double helices producing a three-dimensional network that characterizes the gel formation presented by carrageenan. ${ }^{14}$ $\mathrm{K}$-carrageenan gel formation has been used in bioactive compounds microencapsulation by spray drying. ${ }^{14,15}$

Proteins amphiphilic nature is responsible for reducing the oil-water surface interfacial tension, ${ }^{16}$ which favors their use in hydrophobic compounds microencapsulation. Bovine serum albumin (BSA) represents $42 \%$ of bovine blood proteins ${ }^{17}$ and shows functional technological properties allowing its application in several food matrices. Whey protein presents a globular structure and is soluble at a wide $\mathrm{pH}$ range. The diverse protein group that constitutes whey protein characterizes its functionality for a wide range of food applications. ${ }^{18}$

The properties of gelling and emulsification of whey proteins have been used by their application in food products. The presence of $\beta$-lactoglobulin as the main protein component of whey protein, which confers its gelling property..$^{19}$ Therefore, the physicochemical properties of the whey protein suggest they use in other applications, such as the wall material in the microencapsulation. Whey protein has been reported in volatile compounds microencapsulation by spray drying. ${ }^{12,20,21}$ As the high lactose content in the wall materials was related to accelerating the flavor release and relative humidity, ${ }^{22}$ the application of low-lactose whey protein is suggesting in microencapsulation.

Rice bran proteins have some practical properties such as high foaming capacity and stability over time, as well as emulsifying capacity, similar to casein. ${ }^{23}$ These proteins are obtained from rice bran, a protein-source-potential, low-cost, and high-quality byproduct, containing $75 \%$ glutenine, $15 \%$ globulin, $6 \%$ albumin, and $3 \%$ prolamins. ${ }^{24,25}$ Rice bran proteins characteristics suggest their use as an alternative wall material in microencapsulation. 
Protein-carbohydrate blends used as wall materials may be an alternative for obtaining stable microcapsules. ${ }^{2,26}$ Thus, the simplexcentroid mixture design, considered an efficient methodology to determine optimum components levels and main reagents of formulation development, was used to evaluate the components blends effect. ${ }^{27}$

Therefore, this study aimed to optimize the microcapsules formulation loaded with eugenol, with blends of low-lactose whey protein, rice bran protein, and bovine serum albumin, and with carrageenan as wall material, by spray drying. This study was based on a simplex-centroid mixture design, including the obtained microcapsules characterization.

\section{EXPERIMENTAL}

Eugenol (Sigma-Aldrich, 98\%), ethanol P.A. (Neon, 99.5\%), and Tween-80 (Synth) were used as an organic phase in the blend preparation. Carrageenan (C1013, Sigma-Aldrich, predominantly $\kappa$ and lower amounts of $\lambda$ carrageenan), extracted rice bran protein (50\% protein dry basis), ${ }^{28}$ bovine serum albumin (Sigma-Aldrich, $96 \%)$, and low-lactose whey protein $(2.89 \%$ lactose, and $37 \%$ protein, produced according to Pacheco et al. $)^{29}$ were used as wall materials. In the extraction of protein from rice bran, the defatted rice bran suspension in ultrapure water was adjusted to $\mathrm{pH} 10$ $\left(\mathrm{NaOH} 2 \mathrm{~mol} \mathrm{~L}^{-1}\right)$. The suspension was stirred at $80 \mathrm{rpm}$ for 5 $\mathrm{h}$ at $45{ }^{\circ} \mathrm{C}$. The $\mathrm{pH}$ was corrected to $\mathrm{pH} 4.5$ using $\mathrm{HCl}$ solution ( $3 \mathrm{~mol} \mathrm{~L}^{-1}$ ), and then the suspension was centrifuged for $15 \mathrm{~min}$ $\left(25^{\circ} \mathrm{C}\right)$. The precipitate containing the rice protein was washed and neutralized until reaching $\mathrm{pH} 7$ and spray-dried to obtain rice bran protein. ${ }^{25}$

\section{Simplex-centroid mixture design}

The effects of using carrageenan combined with low-lactose whey protein $\left(X_{1}\right)$, rice bran protein $\left(X_{2}\right)$, and bovine serum albumin $\left(X_{3}\right)$ for eugenol microencapsulation were evaluated by a simplexcentroid mixture design. Carrageenan and protein concentrations were fixed at 0.5 and $3.0 \%(\mathrm{w} / \mathrm{v})$, respectively, in all assays, determined by preliminary tests.

\section{Microcapsules preparation}

The eugenol-loaded microcapsules were obtained from an organic and aqueous phases suspension followed by drying. Eugenol $(0.80 \mathrm{~g})$ and Tween-80 $(0.12 \mathrm{~g})$ were dissolved in ethanol $(10 \mathrm{~mL})$ for $2 \mathrm{~min}$, resulting in the organic phase. For the aqueous phase, carrageenan $(0.5 \%, \mathrm{w} / \mathrm{v})$ was suspended in $200 \mathrm{~mL}$ distilled water at $60{ }^{\circ} \mathrm{C}$ and stirred for $15 \mathrm{~min}$. The separated single proteins were suspended in distilled water by mechanical stirring for $10 \mathrm{~min}$, as per ratios presented in Table 1, resulting in $200 \mathrm{~mL}$ protein suspension $(3 \%, \mathrm{w} / \mathrm{v})$. The organic phase was poured into the aqueous phase and vigorously stirred for $5 \mathrm{~min}$. The suspension obtained was then homogenized using the Fisaton ${ }^{\mathrm{TM}} / 713 \mathrm{D}$ homogenizer at $1500 \mathrm{rpm}$ for $15 \mathrm{~min}$.

The suspension spray drying was done using a mini spray dryer (Labmaq $^{\mathrm{TM}}$-MSD 1.0), with a $500 \mathrm{~mm} \times 150 \mathrm{~mm}$ drying chamber, double fluid type nozzle atomizer with a $1.2 \mathrm{~mm}$ diameter opening. The encapsulating compositions were fed by a peristaltic pump was used at a $0.6 \mathrm{~L} \mathrm{~h}^{-1}$ flow rate, $150{ }^{\circ} \mathrm{C}$ inlet air temperature, $110{ }^{\circ} \mathrm{C}$ outlet temperature, and a $35 \mathrm{~N} \mathrm{~m}^{3} \mathrm{~h}^{-1}$ (normal cubic meter per hour) drying air flow rate. The atomizing air flow was kept at $35 \mathrm{~L} \mathrm{~min}^{-1}$ and $300 \mathrm{kPa}$.

\section{Eugenol retention ratio determination}

The total eugenol concentration ([eugenol $]_{\text {total }}$ ) in the microcapsules obtained (encapsulated and non-encapsulated adhered to the outer part of the microcapsule surface) was obtained using $10 \mathrm{mg}$ microcapsules. The samples were solubilized in $10 \mathrm{~mL}$ ethanol/water $1: 1(\mathrm{v} / \mathrm{v})$ and homogenized in ultrasound (Elmasonic $^{\mathrm{TM}}, \mathrm{P} 60 \mathrm{H}$ ), at $37 \mathrm{kHz}$ frequency and $37 \%$ amplitude. The samples were centrifuged (Hettich Zentrifugen ${ }^{\mathrm{TM}}$, Rotina 420) at $9000 \mathrm{rpm}$ for $15 \mathrm{~min}$. The supernatant was filtered (Millipore $0.45 \mu \mathrm{m})$, and $1 \mathrm{~mL}$ was quantified. Eugenol quantification was performed in an ultra-high performance liquid chromatographer coupled to a UV-Vis detector (UHPLC-UVD170U, Dionex Corporation $^{\mathrm{TM}}$, UltiMate 3000). Methanol/water 85:15 (v/v) ratio was used as mobile phase for eugenol simultaneous separation in the isocratic elution method. Reverse phase C18 Acclain PA2 C18 column $5 \mu \mathrm{m}(250 \times 4.6 \mathrm{~mm})$ was used with $1 \mathrm{~mL} \mathrm{~min}^{-1}$ mobile phase flow and column temperature at $25{ }^{\circ} \mathrm{C}$. Eugenol detection was conducted at $280 \mathrm{~nm}$ with a $20 \mu \mathrm{L}$ sample injection volume. The chromatographic test lasted $10 \mathrm{~min}$ and eugenol retention time was $5.7 \mathrm{~min}$. Eugenol quantification was performed based on a calibration curve of eugenol solutions in methanol at 1.0, 0.8, 0.6, $0.4,0.2$, and $0.1 \mathrm{~g} \mathrm{~L}^{-1}$ concentrations.

Eugenol retention ratio (ER) was determined according to Equation 1.

$$
\operatorname{ER}(\%)=\frac{[\text { eugenol }]_{\text {total }}}{[\text { eugenol }]_{\text {initial }}} \times 100
$$

\section{Eugenol encapsulation efficiency determination}

Non-encapsulated eugenol was removed by washing $10 \mathrm{mg}$ microcapsules samples with $10 \mathrm{~mL}$ ethanol. Microcapsules samples were then dried at $50{ }^{\circ} \mathrm{C}$ in a circulation oven. The dry samples were solubilized in an ethanol/distilled water $1: 1(\mathrm{v} / \mathrm{v})$ ratio solution $(10$ $\mathrm{mL}$ ) and the encapsulated eugenol content was determined by UHPLC as per the described previously methodology. Eugenol encapsulation efficiency (EE) was calculated using Equation 2.

$$
\mathrm{EE}(\%)=\frac{[\text { eugenol }]_{\text {encapsulated }}}{[\text { eugenol }]_{\text {total }}} \times 100
$$

\section{Microcapsules morphology and average size}

Microcapsules morphology and average size were investigated by scanning electron microscopy (SEM, Hitachi, TM 3000) at $15 \mathrm{kV}$. The samples were deposited over adhesive tape and gold-coated with a vacuum sputtering coater. The average microcapsules size was determined by measuring 120 particles from each formulation using SEM images. ${ }^{30}$

\section{Fourier Transform Infrared (FTIR) Analysis}

Pure eugenol, eugenol-loaded microcapsules from assays 3 and 6 , and microcapsules added with $50 \%$ pure eugenol (w/w) (MC $+50 \%$ eugenol) were analyzed by FTIR spectroscopy (Frontier PerkinElmer ${ }^{\mathrm{TM}}$ with attenuated total reflectance mode). The spectra were recorded at wavenumber ranging from 4000 to $700 \mathrm{~cm}^{-1}$, at room temperature, using 32 accumulated scans and a $4 \mathrm{~cm}^{-1}$ resolution.

\section{Thermogravimetric analyses}

Thermogravimetric analyses (TG) were done by simultaneous 
thermo-analyzer STA6000 (PerkinElmer ${ }^{\mathrm{TM}}$ ). About10 mg samples were placed on a platinum crucible and heated from 50 to $600{ }^{\circ} \mathrm{C}$ at a $10{ }^{\circ} \mathrm{C} \mathrm{min}^{-1}$ heating rate, in a dynamic nitrogen atmosphere with a $20 \mathrm{~mL} \mathrm{~min}^{-1}$ flow rate.

\section{Statistical analyses}

Scheffe's canonical model, determined by Equation 3, was used to adjust eugenol retention and encapsulation efficiency experimental data. Linear, quadratic, and cubic models were tested to obtain the respective regression coefficients, using regression and analysis of variance (ANOVA).

$Y=\beta_{1} X_{1}+\beta_{2} X_{2}+\beta_{3} X_{3}+\beta_{12} X_{1} X_{2}+\beta_{13} X_{1} X_{3}+\beta_{23} X_{2} X_{3}+$

$\beta_{123} X_{1} X_{2} X_{3}$

where $Y$ is the response as a function of independent variables $X_{1}$, $X_{2}$, and $X_{3}$ in their codified levels; $\beta_{1}, \beta_{2}$, and $\beta_{3}$ are the regression coefficients of the primary interactions; $\beta_{12}, \beta_{13}$, and $\beta_{23}$ are the regression coefficients of binary interactions; and $\beta_{123}$ is the regression coefficient of ternary interaction.

Response surfaces were determined using mathematic models ( $p \leq 0.05)$ to establish the optimal microencapsulation process conditions based on eugenol retention and encapsulation efficiency. Global desirability function was determined using the Response Desirability Profiling procedure. Statistical analyses were conducted using the Statistica 7.0 software (Statsoft Inc., Tulsa, OK, USA, 2004).

\section{RESULTS AND DISCUSSION}

\section{Eugenol-loaded microcapsules optimization}

Table 1 shows the simplex-centroid mixture design responses for eugenol retention $\left(Y_{1}\right)$, encapsulation efficiency $\left(Y_{2}\right)$, and average microcapsules size $\left(Y_{3}\right)$. Eugenol retention results ranged from $37.9 \pm 0.1 \%$ to $89.7 \pm 1.3 \%$ and for encapsulation efficiency from $0.0 \pm 0.0 \%$ to $80.5 \pm 8.7 \%$, showing they were significantly influenced by wall materials contents.

The average microcapsules size ranged from $3.4 \pm 2.3 \mu \mathrm{m}$ to $4.6 \pm 2.1 \mu \mathrm{m}$. Similar results were reported by Edris et al. ${ }^{31}$ $(4.37 \mu \mathrm{m})$ and Chatterjee \& Bhattacharjee $^{1}$ (1 to $\left.15 \mu \mathrm{m}\right)$, who respectively studied the Nigella sativa L. (black cumin) essential oil and eugenol-rich clove extracts microencapsulation, in gum Arabic and maltodextrin mixture. Locali Pereira, Gonçalves Cattelan \& Nicoletti ${ }^{32}$ when microencapsulated pink pepper essential oil in pectin, soy protein isolate, and maltodextrin by spray drying, obtained values between 4.19 and $5.92 \mu \mathrm{m}$, similar to those found in this study. These microcapsules size variability is typical from the spray drying process.

Eugenol retention $\left(Y_{1}\right)$, encapsulation efficiency $\left(Y_{2}\right)$, average microcapsules size $\left(Y_{3}\right)$, and their respective regression coefficients and mathematical variance analysis models were obtained (Table 2). The mathematical models for $Y_{1}$ and $Y_{2}$ showed significant linear, quadratic, and cubical effects at a $95 \%$ significance level, and due to the $Y_{3}$ model, the results observed for the cubic model did not show any significant effects $(p>0.05)$. Cubic models for a three-componentmixture have linear terms related to the additive model, quadratic terms representing binary interactions, and cubic terms that are related to the ternary interaction effect. The design generally performed to determine the model's coefficient values is named simplex-centroid or special cubic model. Therefore, the linear, quadratic, and cubic terms are usual for simplex-centroid mixture design and thus, have been determined. ${ }^{33}$

Additionally, the coefficients of determination $\left(\mathrm{R}^{2}\right)$ were 0.993 , 0.995 , and 0.830 for $Y_{1}, Y_{2}$, and $Y_{3}$, respectively, and no mathematical model showed any significant lack of fit $(p>0.05)$. However, only $Y_{1}$ and $Y_{2}$ models were significant $(p \leq 0.05)$ to predict the evaluated responses. Then, the response surface, using a simplex centroid mixture design, was applied for valid models $\left(Y_{1}\right.$ and $\left.Y_{2}\right)$. Contours plots are shown in Figure 1 (a, b).

Combined carrageenan and rice bran protein $\left(X_{2}\right)$, or bovine serum albumin $\left(X_{3}\right)$, as microcapsules wall materials resulted in the highest eugenol retention values $\left(Y_{1}\right), 89.7$ and $86.5 \%$, respectively. Eugenol retention determination may be used as an indirect suspension stability measuring. Proteins have volatile compounds entrapping properties by either Van der Waals interactions, hydrogen interaction, or electrostatic interaction. In an aqueous system, interactions between volatile compounds non-polar portions and hydrophobic protein occur. $^{34,35}$ Thus, obtaining the encapsulating suspension favours hydrophobic interactions between eugenol proteins, minimizing the eugenol operational losses under these experimental conditions.

Surface hydrophobicity is linked with emulsifying properties, hence hydrophobic interactions, once hydrophobic interactions have an important role in this protein functional property. Wang et al. ${ }^{36}$ described that rice bran protein concentrate had a lower surface hydrophobicity $(12.2 \pm 2.2)$ than bovine serum albumin $(86.4 \pm 1.2)$ and thus a lower emulsifying property. The low rice bran protein

Table 1. Simplex-centroid mixture design for eugenol retention (\%), encapsulation efficiency (\%), average size ( $\mu$ m) responses, and eugenol-encapsulated content (ppm) of eugenol-loaded microcapsules $(\mathrm{n}=3)$

\begin{tabular}{|c|c|c|c|c|c|c|c|}
\hline \multirow[b]{2}{*}{ Assays } & \multicolumn{3}{|c|}{ Proteins proportion used as encapsulating agents ${ }^{1}$} & \multicolumn{3}{|c|}{ Function response $^{2}$} & \multirow{2}{*}{$\begin{array}{c}\text { Eugenol- } \\
\text { encapsulated }^{6} \\
(\mathrm{ppm})\end{array}$} \\
\hline & $\begin{array}{c}X_{1} \\
\left(\mathbf{x}_{1} / \%\right)\end{array}$ & $\begin{array}{c}X_{2} \\
\left(\mathbf{x}_{2} / \%\right)\end{array}$ & $\begin{array}{c}X_{3} \\
\left(\mathbf{x}_{3} / \%\right)\end{array}$ & $Y_{1}{ }^{3}$ & $Y_{2}^{4}$ & $Y_{3}^{5}$ & \\
\hline 1 & $1.00(3)$ & $0.00(0)$ & $0.00(0)$ & $58.1 \pm 7.7$ & $0.0 \pm 0.0$ & $3.4 \pm 2.3$ & $0.0^{\mathrm{d}} \pm 0.0$ \\
\hline 2 & $0.00(0)$ & $1.00(3)$ & $0.00(0)$ & $89.7 \pm 1.3$ & $27.6 \pm 6.5$ & $3.5 \pm 1.9$ & $40.4^{\mathrm{b}} \pm 9.5$ \\
\hline 3 & $0.00(0)$ & $0.00(0)$ & $1.00(3)$ & $86.5 \pm 0.8$ & $45.1 \pm 3.5$ & $4.6 \pm 2.1$ & $63.8^{\mathrm{a}} \pm 5.0$ \\
\hline 4 & $0.50(1.5)$ & $0.50(1.5)$ & $0.00(0)$ & $37.9 \pm 0.1$ & $47.8 \pm 8.7$ & $4.4 \pm 2.5$ & $29.4^{\mathrm{b}, \mathrm{c}} \pm 5.4$ \\
\hline 5 & $0.50(1.5)$ & $0.00(0)$ & $0.50(1.5)$ & $40.2 \pm 10.4$ & $47.6 \pm 4.8$ & $3.8 \pm 1.7$ & $31.3^{\mathrm{b}, \mathrm{c}} \pm 3.2$ \\
\hline 6 & $0.00(0)$ & $0.501 .5)$ & $0.50(1.5)$ & $52.4 \pm 4.2$ & $80.5 \pm 8.7$ & $3.7 \pm 2.0$ & $69.0^{\mathrm{a}} \pm 7.5$ \\
\hline 7 & $0.33(1)$ & $0.33(1)$ & $0.33(1)$ & $68.3 \pm 0.0$ & $11.7 \pm 2.2$ & $3.8 \pm 2.1$ & $12.9^{\mathrm{c}, \mathrm{d}} \pm 2.4$ \\
\hline 8 & $0.33(1)$ & $0.33(1)$ & $0.33(1)$ & $66.9 \pm 1.4$ & $18.3 \pm 1.1$ & $4.2 \pm 1.9$ & $19.9^{\mathrm{c}} \pm 1.2$ \\
\hline 9 & $0.33(1)$ & $0.33(1)$ & $0.33(1)$ & $62.4 \pm 4.0$ & $17.5 \pm 0.0$ & $*$ & $16.9^{\mathrm{c}, \mathrm{d}} \pm 0.0$ \\
\hline
\end{tabular}

${ }^{1}$ Carrageenan and proteins concentrations were kept fixed in all experimental conditions $-0.5 \%(\mathrm{w} / \mathrm{v})$ and 3\% (w/v), respectively. These concentrations correspond to the final experimental design proportion (suspension). $X_{1}, X_{2}$, and $X_{3}=$ codified values for low-lactose whey protein, rice bran protein, and bovine serum albumin proteins proportions used in mixtures, respectively. $\mathrm{x}_{1}(\%), \mathrm{x}_{2}(\%)$, and $\mathrm{x}_{3}(\%)=$ real concentration values (w/v) of respective proteins added to mixture. ${ }^{2}$ Mean \pm standard deviation. ${ }^{3} Y_{1}=$ eugenol retention $(\%),{ }^{4} Y_{2}=$ encapsulation efficiency $(\%),{ }^{5} Y_{3}=$ average size $(\mu \mathrm{m}),{ }^{6}$ Eugenol-encapsulated $=$ quantified by UHPLC $(\mathrm{n}=3)$. Different letters in the same column indicate statistical differences evaluated by the Tukey test $(p \leq 0.05)$. Not determined. 
Table 2. Regression coefficients and analysis of variance of mathematical models adjusted to response function

\begin{tabular}{lccc}
\hline \multirow{2}{*}{ Coefficient } & \multicolumn{3}{c}{ Response function $^{2}$} \\
\cline { 2 - 4 } Linear & $\boldsymbol{Y}_{1}$ & $\boldsymbol{Y}_{2}$ & $\boldsymbol{Y}_{3}$ \\
$\beta_{1}$ & $58.10^{*}$ & $<-0.01$ & $3.34^{*}$ \\
$\beta_{2}$ & $89.70^{*}$ & $27.60^{*}$ & $3.38^{*}$ \\
$\beta_{3}$ & $86.50^{*}$ & $45.10^{*}$ & $4.39^{*}$ \\
\hline Quadratic & & & \\
$\beta_{12}$ & $-144.00^{*}$ & $136.00^{*}$ & $3.74^{*}$ \\
$\beta_{13}$ & $-128.40^{*}$ & $100.20^{*}$ & - \\
$\beta_{23}$ & $-142.80^{*}$ & $176.60^{*}$ & - \\
\hline
\end{tabular}

\section{Cubic}

\begin{tabular}{lccc}
$\beta_{123}$ & $915.30^{*}$ & $-1465.20^{*}$ & - \\
\hline $\mathrm{R}^{2}$ & 0.993 & 0.995 & 0.830 \\
\hline$p$ value & $0.0218^{*}$ & $0.0159^{*}$ & 0.0509 \\
\hline
\end{tabular}

$X_{1}, X_{2}$, and $X_{3}=$ codified values for low-lactose whey protein, rice bran protein, and bovine serum albumin proportions applied in mixtures, respectively. ${ }^{2} Y_{1}=$ eugenol retention $(\%),{ }^{3} Y_{2}=$ encapsulation efficiency $(\%),{ }^{4} Y_{3}=$ average size $(\mu \mathrm{m}) . *$ Significant at a $95 \%$ confidence level.

hydrophobicity does not facilitate proteins and oils interaction, decreasing oil's absorption capacity. ${ }^{37}$ Such considerations justify the lower $Y_{2}$ value $(27.6 \pm 6.5 \%)$ when using $100 \%$ rice bran protein $\left(X_{2}\right)$. In addition to the properties of the proteins studied, it is important to highlight the interaction between proteins and carrageenan. Proteinpolysaccharide interaction is provided by covalent bonds or physically charge distribution. The structure and stabilizing properties of the mixed protein-polysaccharide layer is depending of biopolymers adsorption on the interface, as well as, affected by $\mathrm{pH}$, ionic strength, and biopolymer charge distribution. ${ }^{38}$

Moreover, rice bran protein $\left(X_{2}\right)$ and bovine serum albumin $\left(X_{3}\right)$ binary interaction used in assay 6 with carrageenan, showed the highest encapsulation efficiency value $\left(Y_{2}\right)(80.5 \pm 8.7 \%)$ and the highest coefficient value $\left(Y_{1}\right)(52.4 \%)$. Fabian, Huynh, \& Ju, ${ }^{39}$ when studying the rice bran proteins interaction with polysaccharides alginate and carrageenan to form complex precipitates reported that rice bran proteins may associate with polysaccharides since the obtained precipitate had foaming and emulsifying abilities. Thus, $X_{2}$ and $X_{3}$ combined with carrageenan favored protein-eugenol and protein-carrageenan interactions, contributing to encapsulation during the spray drying process.

Low-lactose whey protein $\left(X_{1}\right)$ was not efficient for eugenol encapsulation. The $X_{1}$ and carrageenan combination did not allow eugenol loading $\left(Y_{2}=0 \%\right)$ and encapsulation was not efficient when $X_{1}$ was combined with $X_{2}$ or $X_{3}$. Rosenberg \& Sheu ${ }^{40}$ reported that lactose-free whey protein did not contribute to the volatile compounds retention during the microencapsulation process. During spray drying, the presence of lactose in its amorphous state forms a continuous glass phase, in which protein chains are dispersed. Thus, the low-lactose whey protein prevents the film formation during drying and hinders eugenol entrapping.

The ternary protein mixture negatively affected the encapsulation efficiency $\left(Y_{2}\right)$ and such effect may be observed by the negative value obtained for the $\beta_{123}$ coefficient value, as shown in Table 2 . Therefore, the $\mathrm{X}_{2}$ and $\mathrm{X}_{3}$ proportions in the experimental conditions may not have been efficient to improve the film properties. Furthermore, due to $X_{2}$ and $X_{3}$ results in the binary interactions, the low-lactose whey protein $\left(X_{1}\right)$ presence in the ternary interaction may have hampered the film formation process.
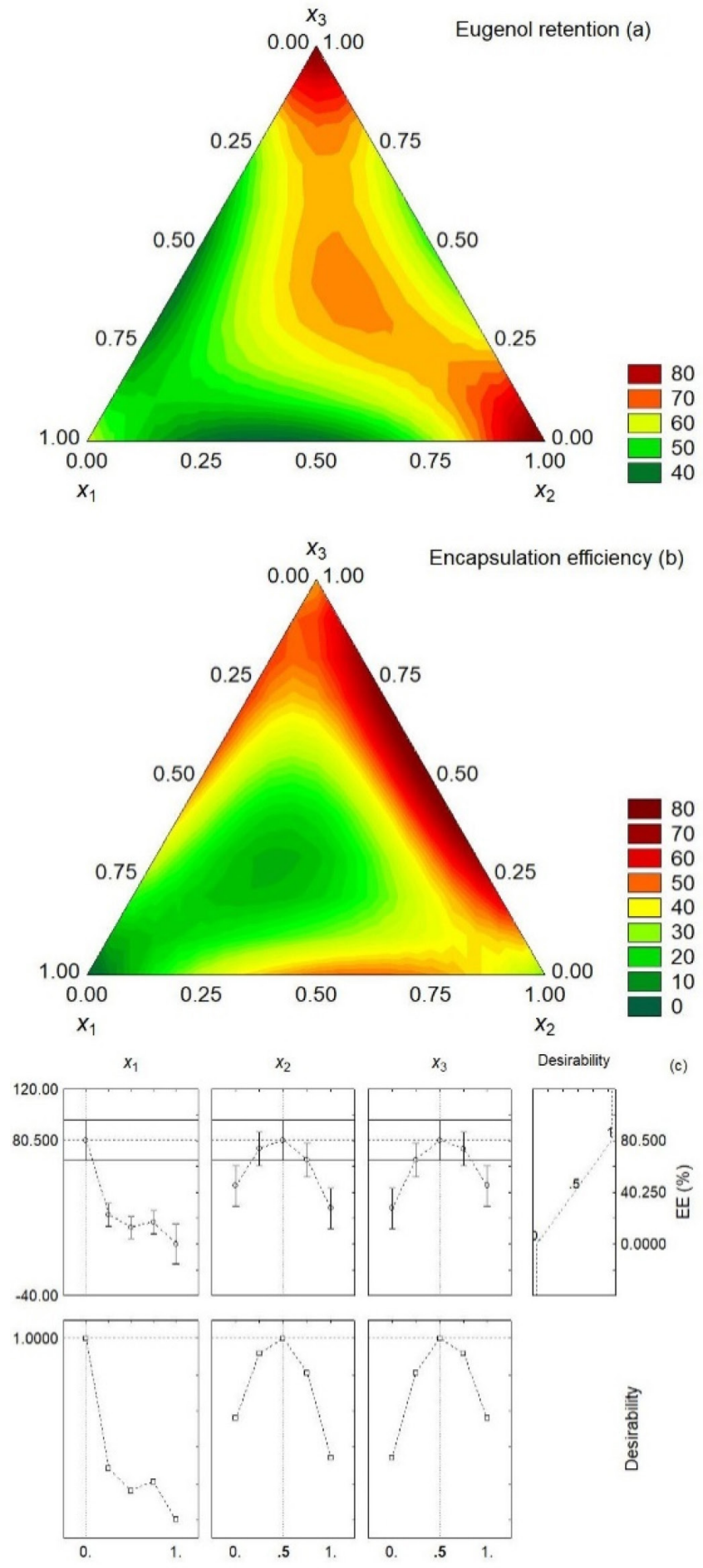

Figure 1. Simplex centroid mixture design for (a) eugenol retention, (b) encapsulation efficiency responses, and (c) optimal proportions for eugenol encapsulation efficiency (EE \%) using the desirability parameters from lowlactose whey protein $\left(X_{1}\right)$, rice bran protein $\left(X_{2}\right)$, and bovine serum albumin $\left(X_{3}\right)$ mixtures in eugenol microencapsulation $(n=3)$

An optimal region prediction for the eugenol-loaded microcapsules formulation was possible from the estimated $Y_{1}$ and $Y_{2}$ responses analyses, by observing the response surface presented in Figures1a and $1 \mathrm{~b}$, as well the optimal parameters. However, as the encapsulation efficiency $\left(Y_{2}\right)$ is a direct determination of the eugenol amount encapsulated in the microcapsules, such response was the only one used to determine the desirability parameters (Figure 1c). For 
the microcapsules produced, the optimal encapsulation efficiency (Figure 1c) occurred when $X_{1}=0, X_{2}=0.5$ and $X_{3}=0.5$ from assay 6 (Table 1) with $Y_{2}(80.5 \%)$. Considering the optimum encapsulation efficiency model, the predicted value was $80.3 \%$. A validation assay was performed in duplicate using the optimum condition variables, and the encapsulation efficiency value obtained was $79.9 \pm 7.9$, with a relative deviation of $0.50 \%$, compared to predict value. No statistically significant difference $(p>0.05)$ was found between the observed and the predicted responses by the encapsulation efficiency model; therefore, the model was validated.

Assay 6, which considers binary $X_{2}$ (rice bran protein) and $X_{3}$ (bovine serum albumin) interaction with carrageenan, showed the highest value for eugenol-encapsulated content $(69.0 \pm 7.5 \mathrm{ppm})$, and it was statistically similar $(p>0.05)$ to assay 3 when $X_{3}$ primary interaction with carrageenan was $63.8 \pm 5.0 \mathrm{ppm}$. Assay 2, which considers $X_{2}$ primary interaction with carrageenan, had a $40.4 \pm 9.5 \mathrm{ppm}$ content value. Despite the high suspension stability obtained from assays 2 and 3, these proteins were not able to effectively bind eugenol when used with carrageenan alone, which reinforces the effect of the $\mathrm{X}_{2}$ and $\mathrm{X}_{3}$ combined use in the experimental conditions.

\section{Microcapsules Characterization}

\section{Eugenol-loaded microcapsules morphology}

Figure 2 presents the eugenol-loaded microcapsules SEM images. A spherical morphology may be observed in the microcapsules' SEM images obtained using the $X_{2}$ (rice bran protein) and $X_{3}$ (bovine serum albumin) mixture with carrageenan (Figures 2e and 2f). This microcapsule outer surface characteristic indicates the existence of solid walls ensuring low permeability
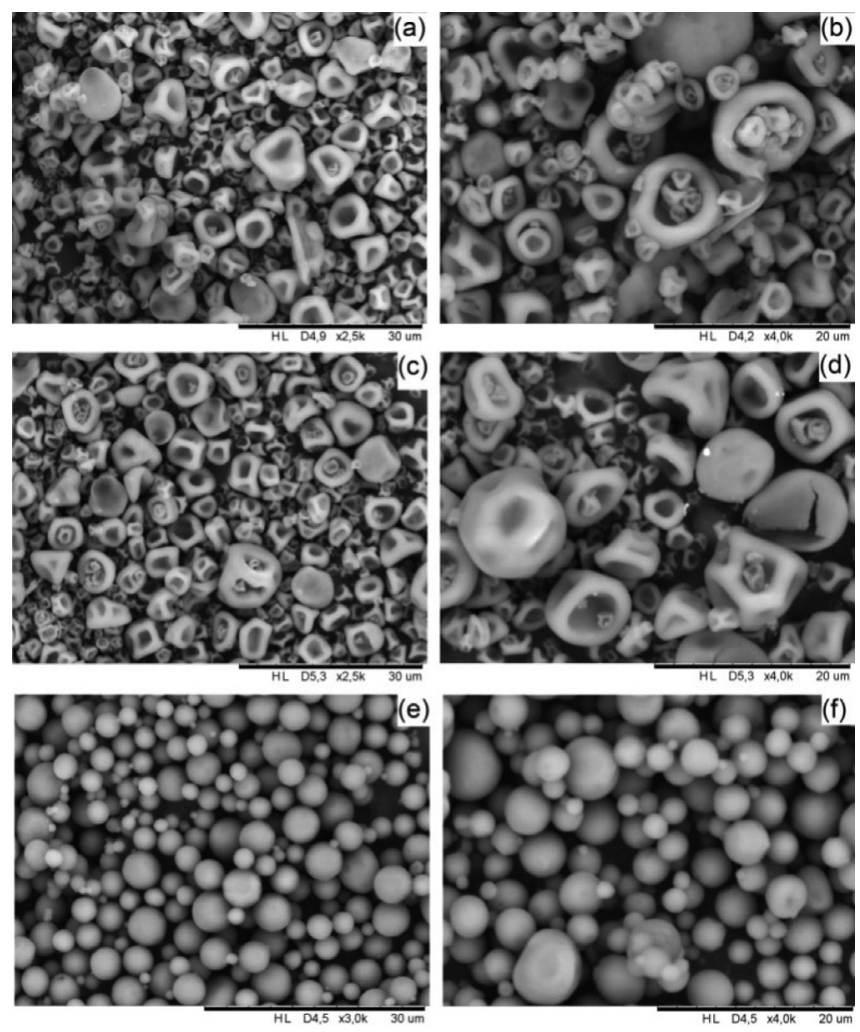

Figure 2. Eugenol-loaded microcapsules SEM images of carrageenan combined with rice bran protein $(a, b)$; bovine serum albumin $(c, d)$; and rice bran protein and bovine serum albumin binary mixture $(e, f)$ produced by spray-drying. 2500x (left) and 4000x (right) magnification to gases, better protection, and essential eugenol retention. ${ }^{27}$ This morphologic characteristic corroborates with the encapsulation efficiency results shown, indicating better volatile compounds preservation in the essential oil, which implies lower permeability to gases that may cause oxidation. ${ }^{32}$

However, the $X_{1}$ (low-lactose whey protein) and $X_{3}$ (bovine serum albumin) mixture and the isolated use of $X_{2}$ (rice bran protein) or $X_{3}$ (bovine serum albumin) with carrageenan resulted in microcapsules with deformations and surface roughness, suggesting that these mixtures used as wall materials were not suitable for obtaining microcapsules with good elasticity during the drying process. Some microcapsules have also presented fissures that characterized collapse (Figure $2 \mathrm{~b}$ and $2 \mathrm{~d}$ ). Similar results were reported by Edris et al. ${ }^{31}$ when they obtained essential oil microcapsules by spray drying. The microcapsules roughness characteristic may be due to instantaneous sprayed oil resin emulsion droplets shrinkage during the early spray drying stages.

\section{Fourier Transform Infrared (FTIR-ATR) spectroscopy}

FTIR spectroscopy was used to investigate the microcapsules encapsulation efficiency. Bioactive compounds characteristic IR absorption bands in microcapsules FTIR spectra suggest their presence on the microcapsules surface, indicating low encapsulation efficiency. ${ }^{41}$

FTIR spectra were obtained for the assays that presented the highest encapsulated eugenol content (assays 3 and 6) and for the microcapsules added with pure eugenol $(50 \% \mathrm{w} / \mathrm{w})$, as shown in Figure 3.

For the eugenol FTIR spectrum, absorption bands at $1510 \mathrm{~cm}^{-1}$ $v(\mathrm{C}=\mathrm{C}$ aromatic ring $), 1265 \mathrm{~cm}^{-1} v(\mathrm{C}-\mathrm{O}), 1230 \mathrm{~cm}^{-1} v(\mathrm{C}-\mathrm{O}-\mathrm{C})$, and $1032 \mathrm{~cm}^{-1} v(\mathrm{C}-\mathrm{O}$ aromatic ring) were observed. Such bands were also reported by Chowdhry, Ryall, Dines \& Mendham, ${ }^{42}$ and by Piletti et al. ${ }^{43}$

Microcapsules samples FTIR spectra showed pronounced bands characteristic of wall material used in microencapsulation. The amide II band present in rice bran protein and bovine serum albumin was observed at $1535 \mathrm{~cm}^{-1} v(\mathrm{~N}-\mathrm{H}$ bending /C-N stretching $){ }^{44} \mathrm{It}$ was noted a band at $1065 \mathrm{~cm}^{-1}$ attributed to carrageenan glycosidic bond. ${ }^{45,46}$ In addition to the high intensity band characteristic of wall material, shoulders were observed in FTIR spectrum of microcapsules added with pure eugenol $(\mathrm{MC}+50 \%)$, indicating the presence of this compound in the system (Figure 3a). The shoulders observed at $1517 \mathrm{~cm}^{-1}$ and $1039 \mathrm{~cm}^{-1}$, corresponding to eugenol, were also identified in MC 3 and MC 6 samples, however, with a lower intensity than that observed in the $\mathrm{MC}+50 \%$ spectrum.

To facilitate observation of eugenol characteristic bands in microcapsules' FTIR spectra, bands deconvolution from 1560 to $1500 \mathrm{~cm}^{-1}$, and from 1090 to $1020 \mathrm{~cm}^{-1}$ was performed for MC 6 (Figure 3b). A coefficient of determination $\left(\mathrm{R}^{2}\right)$ higher than 0.995 was obtained for both deconvoluted bands, showing optimal data fitting. The shoulders corresponding to eugenol (Figure 3b) were observed, confirming its presence in the microcapsules' wall.

\section{Thermogravimetric analyses}

Thermogravimetric analyses (TG) and their derivatives (DTG) for carrageenan (CA), rice bran protein (RBP), bovine serum albumin (BSA), and eugenol, as well as eugenol-loaded microcapsules assays 3 (MC 3) and 6 (MC 6), are shown in Figure 4. According to TG and DTG analyses, eugenol presented a single thermal loss of weight event at $246{ }^{\circ} \mathrm{C}$, which may be characterized as eugenol evaporation. Nuchuchua et al. ${ }^{47}$ reported a similar value $\left(241^{\circ} \mathrm{C}\right)$ for the same event. Also, TG analysis showed a microcapsules' loss of weight, with the increase of temperature similar to the one for wall 


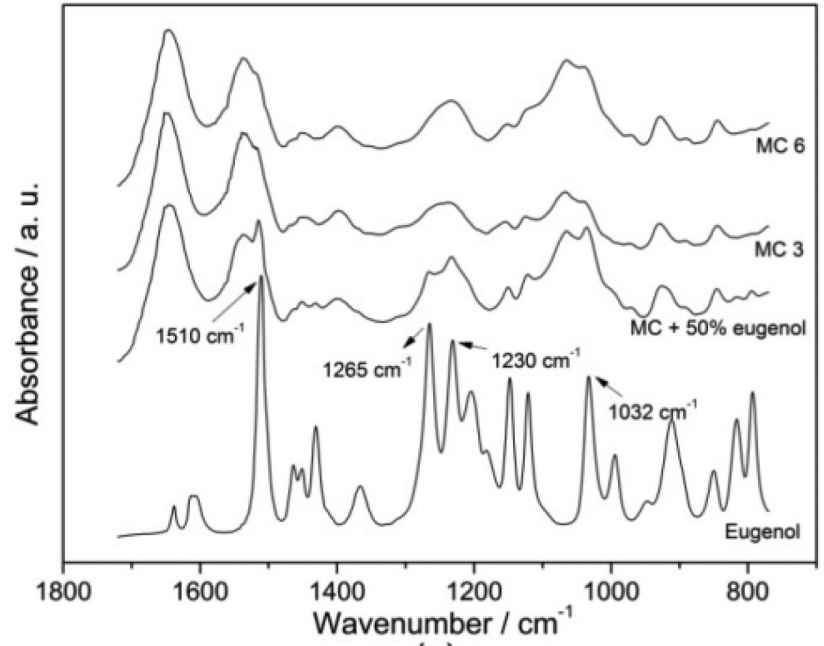

(a)

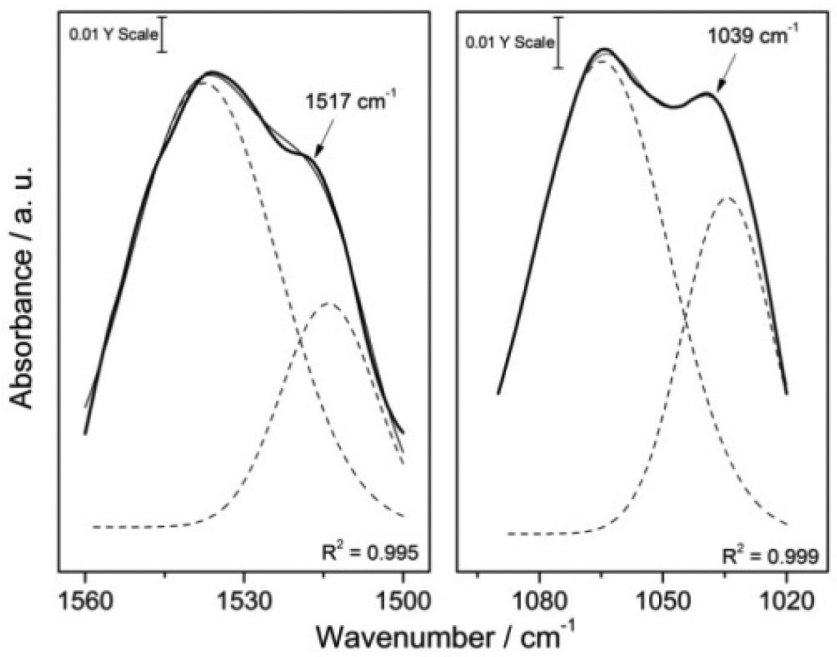

(b)

Figure 3. FTIR-ATR spectrum of (a) eugenol-loaded microcapsules assay 6 (MC 6), assay 3 (MC 3), eugenol-loaded-microcapsules assay 6 added with $50 \%$ pure eugenol $(w / w)(M C+50 \%$ eugenol $)$, and pure eugenol; FTIR-ATR deconvolution spectrum of $(b)$ eugenol microencapsulated in carrageenan, rice bran protein and bovine serum albumin (MC 6) in a wavenumber ranging from 1560 to $1500 \mathrm{~cm}^{-1}$ (left) and from 1090 to $1020 \mathrm{~cm}^{-1}$ (right) showing eugenol bands presence at $1517 \mathrm{~cm}^{-1}$ and $1039 \mathrm{~cm}^{-1}$. Original FTIR-ATR spectrum (thick solid line); Gaussian curve-fit (solid line); Peaks from deconvolution analysis (dashed lines)

materials and less intense than that for pure eugenol. This result suggests the wall materials protective effect on eugenol.

For microcapsules, DTG showed four main thermal loss of weight events. The first one occurred at $100{ }^{\circ} \mathrm{C}$ for both assays, which correspond to microcapsules moisture content (about 7\%). Another thermal loss of weight event was noted at $250{ }^{\circ} \mathrm{C}$ that may be from eugenol evaporation. Tanaka, Lu, Yuasa \& Yamaura ${ }^{48}$ reported loss of weight events to $k$-carrageenan, at $220^{\circ} \mathrm{C}$, however, this difference in thermal degradation temperature between carrageenan systems may be due to each system morphological conformation, dependent on processing conditions. Although both microcapsules were added with the same carrageenan amounts, MC 3 assay presented a more intense peak than MC 6 . This may be due to the presence of a greater amount of non-encapsulated eugenol in the microcapsules from the MC 3 assay. The DTG peaks at $315^{\circ} \mathrm{C}$ and $307{ }^{\circ} \mathrm{C}$ for MC 3 and MC 6 assays, respectively, characterize the microcapsules collapse and, (a)

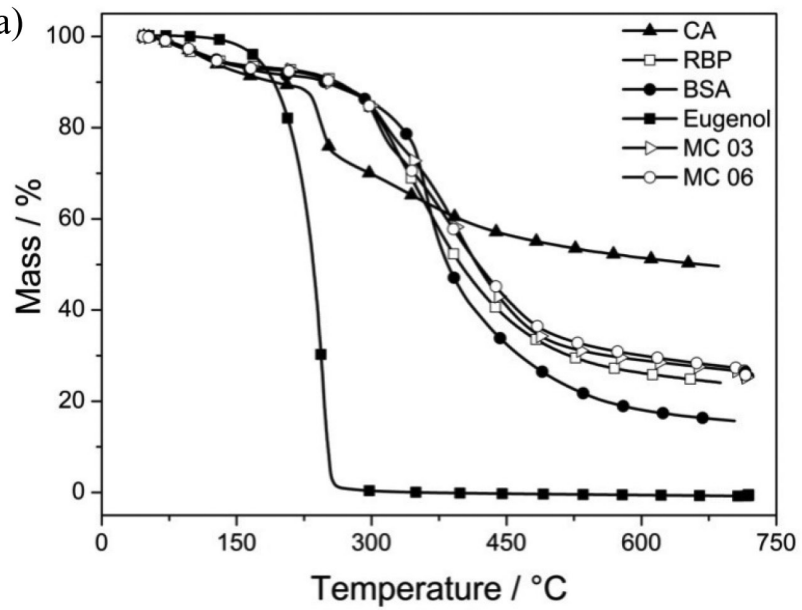

(b)

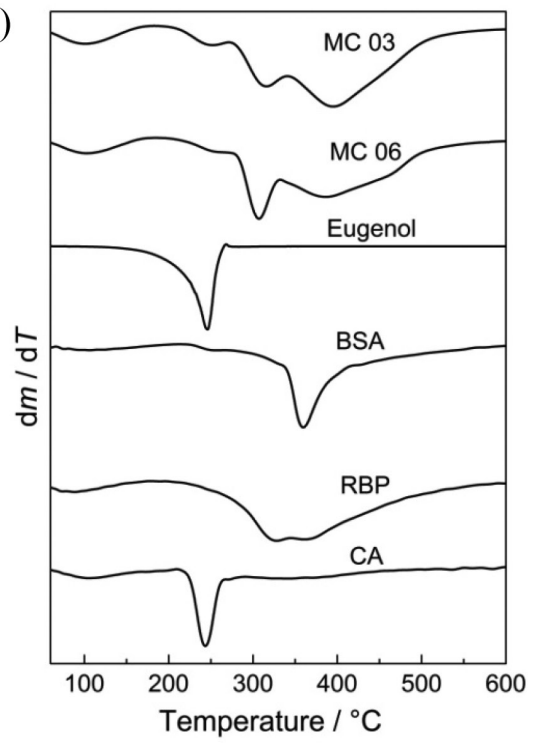

Figure 4. TG (a) and DTG (b) analyses of eugenol microencapsulated in carrageenan and bovine serum albumin (MC 3), eugenol microencapsulated in carrageenan, rice bran protein, and bovine serum albumin (MC 6), and the pure materials - carrageenan $(C A)$, rice bran protein $(R B P)$, bovine serum albumin (BSA), and eugenol

hence, eugenol release. Such results showed that the encapsulation process resulted in increased eugenol thermal stability inside these systems, improving eugenol retention and encapsulation efficiency.

The peak associated with microcapsules collapse was more pronounced in MC 6 assay, which represents an encapsulated eugenol rate higher than the non-encapsulated one. Microcapsules wall material thermal degradation in both assays was noted at $390^{\circ} \mathrm{C}$.

\section{CONCLUSIONS}

Simplex-centroid mixture design may be used to maximize encapsulation efficiency of eugenol-loaded microcapsules using carrageenan spray drying and protein blends as wall materials. The use of rice bran protein and bovine serum albumin with carrageenan produced microcapsules with the highest eugenol retention; this effect may be correlated to suspension stability prior to drying. Thus, the binary interaction between these proteins resulted in the highest encapsulation efficiency allowing for better conditions to obtain eugenol-loaded microcapsules, as per desirability parameters and 
encapsulation efficiency response surface methodology. Optimum point microcapsules showed a spherical morphology and fissure-free, with such systems' wall surface showing a solid appearance, as well as good-film-formation particles. The FTIR-ATR and thermal analyses confirmed eugenol encapsulation, showing an eugenol predominance inside the microcapsules at temperatures above $300{ }^{\circ} \mathrm{C}$.

\section{ACKNOWLEDGMENTS}

The authors would like to thank CAPES, CNPq, and Fundação Araucária for their financial support.

\section{REFERENCES}

1. Chatterjee, D.; Bhattacharjee, P.; J. Food Eng. 2013, 117, 545.

2. Talón, E.; Vargas, M.; Chiralt, A.; González-Martínez, C.; LWT - Food Sci. Technol. 2019, 113, 1 .

3. García-García, R.; López-Malo, A.; Palou, E.; J. Food Sci. 2011, 76, 95.

4. Alvarenga Botrel, D.; Vilela Borges, S.; Fernandes, R. V. B.; Dantas Viana, A.; Costa, J. M. G.; Marques, G. R.; Int. J. Food Sci. Technol. 2012, 47, 2289.

5. Gharsallaoui, A.; Roudaut, G.; Chambin, O.; Voilley, A.; Saurel, R.; Food Res. Int. 2007, 40, 1107.

6. Ré, M. I.; Drying Technol. 1998, 16, 1195.

7. Reineccius, G. A.; Drying Technol. 2004, 22, 1289.

8. De Souza, J. R. R.; Feitosa, J. P. A.; Ricardo, N. M. P. S.; Trevisan, M. T. S.; De Paula, H. C. B.; Ulrich, C. M.; Owen, R. W.; Food Hydrocolloids 2013, 33, 10.

9. Wang, Y.; Lu, Z.; Lv, F.; Bie, X.; Eur. Food Res. Technol. 2009, 229, 391.

10. Zbicinski, I.; Delag, A.; Strumillo, C.; Adamiec, J.; Chem. Eng. J. 2002, $86,207$.

11. Dubey, R.; Shami, T. C.; Bhasker Rao, K. U.; Def. Sci. J. 2009, $59,82$.

12. Agustinisari, I.; Mulia, K.; Nasikin, M.; Appl. Sci. 2020, 10, 1.

13. Trčková, J.; Štetina, J.; Kánský, J.; Int. Dairy J. 2004, 14, 337.

14. Chan, S. W.; Mirhosseini, H.; Taip, F. S.; Ling, T. C.; Nehdi, I. A.; Tan, C. P.; Food Sci. Biotechnol. 2016, 25, 53.

15. Dima, C.; Cotârlet, M.; Alexe, P.; Dima, S.; Innov. Food Sci. Emerg. Technol. 2014, 22, 203.

16. Lam, R. S. H.; Nickerson, M. T.; Food Chem. 2013, 141, 975.

17. Prata, A. S.; Sgarbieri, V. C.; Ciênc. Tecnol. Aliment. 2005, 25, 327.

18. Mehyar, G. F.; Al-Isamil, K. M.; Al-Ghizzawi, H. M.; Holley, R. A.; J. Food Sci. 2014, 79, 1939

19. Gunasekaran, S.; Ko, S.; Xiao, L.; J. Food Eng. 2007, 83, 31.

20. Giroux, H. J.; Britten, M.; J. Microencapsulation 2011, 28, 337.

21. Rodea-González, D. A.; Cruz-Olivares, J.; Román-Guerrero, A.; Rodríguez-Huezo, M. E.; Vernon-Carter, E. J.; Pérez-Alonso, C.; J. Food Eng. 2012, 111, 102.

22. Huang, Z.; Li, K.; Ma, L.; Chen, F.; Liao, X.; Hu, X.; Ji, J.; LWT-Food Sci. Technol. 2021, 141, 110857.
23. Chandi, G. K.; Sogi, D. S.; J. Food Eng. 2007, 79, 592.

24. Hamada, J. S.; J. Food Sci. 2000, 65, 305.

25. Han, S. W.; Chee, K. M.; Cho, S. J.; Food Chem. 2015, 172, 766.

26. Favaro-Trindade, C. S.; de Pinho, S. C.; Braz. J. Food Technol. 2008, 11, 103.

27. Cano-Higuita, D. M.; Alexander, H.; Vélez, V.; Regina, V.; Telis, N.; Cienc. Agrotecnol. 2015, 39, 173.

28. Bernardi, S.; Corso, M. P.; Baraldi, I. J.; Colla, E.; Canan, C.; Int. Food Res. J.2018, 25, 1133.

29. Pacheco, M. T. B.; Dias, N. F. G.; Baldini, V. L. S.; Tanikawa, C.; Sgarbieri, V. C.; Ciênc. Tecnol. Aliment. 2005, 25, 333.

30. Fritzen-Freire, C. B.; Prudêncio, E. S.; Amboni, R. D. M. C.; Pinto, S. S.; Negrão-Murakami, A. N.; Murakami, F. S.; Food Res. Int. 2012, 45, 306.

31. Edris, A. E.; Kalemba, D.; Adamiec, J.; Piaotkowski, M.; Food Chem. 2016, 204, 326.

32. Locali Pereira, A. R.; Gonçalves Cattelan, M.; Nicoletti, V. R.; Colloids Surf., A 2019, 581, 123806.

33. Dejaegher, B.; Vander Heyden, Y.; J. Pharm. Biomed. Anal. 2011, 56, 141.

34. Damodaran, S. In Química de alimentos de Fennema; Damodaran, S., Parkin, K. L., Fennema, O. R., eds.; Artmed: Porto Alegre, 2010.

35. Albano, K. M.; Nicoletti, V. R.; Ultrason. Sonochem. 2018, 41, 562.

36. Wang, M.; Hettiarachchy, N. S.; Qi, M.; Burks, W.; Siebenmorgen, T.; J. Agric. Food Chem. 1999, 47, 411.

37. Zhang, H. J.; Zhang, H.; Wang, L.; Guo, X. N.; Food Res. Int. 2012, 47, 359.

38. Faridi Esfanjani, A.; Jafari, S. M.; Assadpour, E.; Food Chem. 2017, 221, 1962.

39. Fabian, C. B.; Huynh, L. H.; Ju, Y. H.; LWT-Food Sci. Technol. 2010, 43,375 .

40. Rosenberg, M.; Sheu, T.-Y.; Int. Dairy J. 1996, 6, 273.

41. Woranuch, S.; Yoksan, R.; Carbohydr. Polym. 2013, 96, 578.

42. Chowdhry, B. Z.; Ryall, J. P.; Dines, T. J.; Mendham, A. P.; J. Phys. Chem. A 2015, 119, 11280

43. Piletti, R.; Bugiereck, A. M.; Pereira, A. T.; Gussati, E.; Dal Magro, J.; Mello, J. M. M.; Dalcanton, F.; Ternus, R. Z.; Soares, C.; Riella, H. G.; Fiori, M. A.; Mater. Sci. Eng., C 2017, 75, 259.

44. Somboonsub, S.; Thawornchinsombut, S.; J. Food Sci. Agric. Technol. 2015, 1,63 .

45. Servagent-Noinville, S.; Revault, M.; Quiquampoix, H.; Baron, M.-H.; J. Colloid Interface Sci. 2000, 221, 273.

46. Yu, F.; Cui, T.; Yang, C.; Dai, X.; Ma, J.; Chemosphere 2019, 237, 124417 .

47. Nuchuchua, O.; Saesoo, S.; Sramala, I.; Puttipipatkhachorn, S.; Soottitantawat, A.; Ruktanonchai, U.; Food Res. Int. 2009, 42, 1178.

48. Tanaka, T.; Lu, T.; Yuasa, S.; Yamaura, K.; Polym. Int. 2001, 50, 1103. 